\title{
THE EFFECT OF INDIVIDUALISM AND COLLECTIVISM AND SELF-CONFIDENCE ON MOTIVATION TO LEAD: A STUDY ON GENERATION Z AS A POTENTIAL WORKFORCE
}

\author{
DOI: 10.17261/Pressacademia.2021.1420
}

PAP- V.13-2021(9)-p.42-47

Yavuz Selim Duger

Kutahya Dumlupinar University, Faculty of Economics and Administrative Sciences, International Trade and Finance, Kutahya, Turkey. yselim.duger@dpu.edu.tr, ORCID: 0000-0003-3523-9671

To cite this document

Duger, Y.S., (2021). The effect of individualism and collectivism and self-confidence on motivation to lead: a study on generation $Z$ as a potential workforce. PressAcademia Procedia (PAP), V.13, 42-47.

Permanent link to this document: $h$ ttp://doi.org/10.17261/Pressacademia.2021.1420

Copyright: Published by PressAcademia and limited licensed re-use rights only.

\begin{abstract}
Purpose- In this study, it is aimed to determine the effect of individualism \& collectivism cultural tendencies and self-confidence levels of Generation Z, who are seen as a potential workforce, on their motivation to lead.

Methodology- The data were obtained from Kütahya Dumlupınar University students. Generation Z, especially born before 2000, was selected as the target group within the scope of the research, and research was conducted on 297 participants. In the questionnaire form; there are 48 questions to measure age, gender, individualism \& collectivism, self-confidence, and motivation to lead.

Findings- According to the research results; horizontal individualism has a significant and positive effect on affective identity leadership motivation, vertical individualism has a significant and positive effect on social-normative leadership motivation, horizontal collectivism has a significant and positive effect on social-normative and non-calculative leadership motivation, vertical collectivism has a significant and positive effect on affective identity and social-normative leadership motivation. Also, self-confidence has a significant and positive effect on social-normative leadership motivation.

Conclusion- Conducting detailed research on the motivation sources of the generation $\mathrm{z}$ individuals representing the workforce of the near future is of great importance both in terms of academic and business life.

Keywords: Individualism and collectivism, self-confidence, motivation to lead, generation z.

JEL Codes: M10, M50, M54

BíREYCILIK \& KOLEKTIVIZM VE ÖZ-GÜVENIN LIDERLIK ETME MOTIVASYONUNA ETKISI: POTANSIYEL IŞGÜCÜ OLAN Z KUŞAĞı ÜZERINDE BIR ARAŞTIRMA
\end{abstract}

\section{ÖZET}

Amaç- Bu çalışmada, potansiyel işgücü olarak görülen Z kuşağının bireycilik \& kolektivizm kültürel eğilimlerinin ve öz-güven seviyelerinin, liderlik etme motivasyonuna olan etkisini belirlemek amaçlanmaktadır.

Yöntem- Gerekli olan veriler Kütahya Dumlupınar Üniversitesi öğrencilerinden elde edilmiştir. Araştırma kapsamında, özellikle 2000 yılı öncesi doğan Z kuşağı hedef kitle olarak seçilmiş ve 297 katılımcı üzerinde araştırma yapılmıştır. Anket formunda; yaş, cinsiyet, bireycilik \& kolektivizm, öz-güven ve liderlik etme motivasyonunu ölçmeye yönelik 48 soru yer almaktadır.

Bulgular- Araştırma sonuçlarına göre; yatay bireyselliğin duygusal kimlik liderlik etme motivasyonu üzerinde, dikey bireyselliğin sosyalnormatif liderlik etme motivasyonu üzerinde, yatay kolektivizmin sosyal-normatif ve çıkarsız liderlik etme motivasyonu üzerinde, dikey kolektivizmin duygusal kimlik ve sosyal-normatif liderlik etme motivasyonu üzerinde anlamlı ve olumlu etkisi vardır. Ayrıca, öz güvenin sosyalnormatif liderlik etme motivasyonu üzerinde anlamlı ve olumlu bir etkisi vardır.

Sonuç- Yakın geleceğin işgücünü temsil eden z kuşağı bireylerin, motivasyon kaynaklarına yönelik detaylı araştırmaların yapılması hem akademik açıdan hem de iş hayatı açısından büyük önem arz etmektedir.

Anahtar Kelimeler: Bireycilik ve kolektivizm, öz-güven, liderlik etme motivasyonu, z kuşağı.

JEL Kodları: M10, M50, M54 


\section{Gíriş}

I. Dünya savaşından günümüze kadar geçen süreçte yaşanan toplumsal ve siyasi olaylar, teknolojik gelişmeler, küreselleşme vb. çeşitli gelişmeler insanlar üzerinde tutumsal, davranışsal ve kişilik olarak farklılaşmaya yol açmıştır. Belirli olaylar ya da gelişmeler sonrasında dünyaya gelen insanların bakış açıları bir önceki nesle göre farklılık göstermeye başlamış ve bilim adamları tarafından bu farklıık sessiz kuşak, bebek patlaması kuşağı, x, y, z vb. kuşak olarak isimlendirilmiştir. Çeşitli değişim ve gelişmelere bağı ortaya çıkan farklı kuşaklar değişik özelliklerle karakterize edilmektedir. Söz konusu meydana gelen bu kuşak farklılaşmaları, toplumsal ilişkilerden, aile ilişkilerine, işletmelerin örgüt yapılarından yönetim şeklinin belirlenmesine kadar çeşitli etkileri bulunmaktadır. Bu noktada işletmelerin, iş hayatına her geçen gün dâhil olan z kuşağından daha yüksek performans elde edebilmek için onların genel ihtiyaç ve beklentilerini, tutumsal ve davranışsal özelliklerini, motivasyon kaynaklarını çok iyi analiz etmeleri gerekmektedir.

Bu bağlamda, potansiyel işgücü olarak kabul edilen z kuşağı bireylerin, liderlik rolünü üstlenme noktasındaki motivasyonlarını belirlemekte önemlidir. Liderlik üzerine yapılan araştırmalar genellikle mevcut olan liderin özellik ve davranışlarına odaklanmaktadır. Liderin, çalışanları daha yüksek performans elde edebilmek için nasıl motive edeceği konusu yaygın olarak ele alınmaktadır. Buna rağmen, bireylerin liderlik etme noktasındaki motivasyon kaynakları yeterince araştırılmamıştır. Bununla birlikte öz-güven, bireylerin tutumlarını, davranışlarını, motivasyonlarını ve performansını etkileyen önemli bir unsurdur. Değerli bir bireysel varlık olarak kabul edilen öz-güvenin oluşumuna, bireylerin elde ettiği başarılar ya da karşılaştığı başarısızlıkların büyük etkisi olmaktadır. Öz-güveni yüksek olan kişiler, başarısızlıktan korkmayan, mücadeleci ve değiştirebileceğine inandığı koşulları değiştirecek cesarete sahiptir. Öz-güveni düşük olan kişiler ise kendi başına hareket edemeyen, başkalarının onayına muhtaç, başarısızlıktan korkan ve mücadeleci iradeye sahip olmayanlardır (Kaya ve Taştan, 2020: 299). Bu noktada, z kuşağı bireylerin öz-güven düzeylerinin, liderlik etme motivasyonuna olan etkisi araştırılması gereken alanlar arasında yer almaktadır. Z kuşağı bireylerin, toplumsal kültürü belirleyen önemli boyutlardan bir olarak kabul edilen, bireycilik \& kolektivizm eğilimleri tutum, davranış ve motivasyonları üzerinde önemli etkileri olduğu düşünülmektedir.

Bu çalışmada, potansiyel işgücü olarak görülen Z kuşağının bireycilik \& kolektivizm kültürel eğilimlerinin ve öz-güven seviyelerinin liderlik etme motivasyonuna olan etkisini belirlemek amaçlanmaktadır.

\section{LITERATÜR INCELEMESI}

\subsection{Z Kuşağı}

Z kuşağının şekillenmesinde özellikle, teknolojik gelişmişlik, ekonomik refah, toplumsal yapı ve ebeveynler büyük rol oynamıştır (Sladek ve Grabinger 2013: 7). Z kuşağı, diğer kuşaklarından farklı bir aile yapısında yetişmiştir; yaşlı ebeveynler, çalışan anne, ev işlerine yardımcı olan baba gibi. Daha erken eğitime başlayan, genç yaşta pazarlamaya unsurlarına maruz kalan, teknoloji okuryazarlılığı yüksek olan, internet meraklısı z kuşağı bireyler, diğer kuşaklardan farklı karakteristik özellikler sergilemektedir (Levickaite, 2010: 173).

Z kuşağının genel olarak olumlu özellikleri; bilgiyi hızlı yorumlayabilen, çeşitliliğe tolerans gösteren, teknoloji odaklı, sanal ağlar üzerinden iletişim kuran, görsel iletişime önem veren, iyi eğitimli, kendini sürekli geliştiren, sonuç odaklı, yenilikçi, işbirlikçi, yüksek teknik yeterliliğe sahip ve çoklu görevlerde beceriklilik gösterebilendir. Z kuşağının olumsuz olarak algılanan özellikleri ise; aidiyet duygusu az, çabuk vazgeçen, bireysel hareket eden, tatminsiz, kararsız, doğuştan tüketici, düşük düzeyde konsantrasyona sahip, odaklanma problemi yaşayan, özgürlüğüne düşkün, esnekliği seven, aceleci ve sabırsızdır (Düzgün, 2020: 224-225; Taş vd., 2017: 1037-1040).

Z kuşağı bireylerin, değişimin ve teknolojik gelmelerin çok hızlı yaşandığı bir dönemde dünyaya gelmiş olmaları, karakteristik olarak diğer kuşaklara göre belirgin farklılık göstermelerine yol açmıştır (Altuntuğ, 2012: 206). Bu değişimler iş ortamında da kendini göstermektedir. İ̧̧ doyumu ve sadakati düşük, her şeyden çabuk sıkılan, esnekliği seven ve grup çalışmasına yatkın olmayan z kuşağı bireylerin, yönetilmesi ve çalıştırılması yöneticilerin üstesinden gelmesi gereken sorunlar olarak görülmektedir.

Bu noktada, çalışma ortamının daha eğlenceli, risk almaya açık, daha katılımcı ve demokratik, prosedürlerin az, hiyerarşiden uzak ve esnek çalışmaya olanak veren bir hale dönüştürülmesi, z kuşağı çalışanların elde tutulmasına ve daha verimli çalışmasına imkânı sağlayabilir. Para kazanmak kadar iş tatmini de önem veren z kuşağı bireylerin etkin yönetilebilmesi için yeni çalışma modelleri ve yönetim tarzlarının benimsenmesi gerekmektedir.

\subsection{Bireycilik \& Kolektivizm ve Öz-Güven}

Toplumları tanımlayan kültür boyutlarından biri olarak kabul edilen bireycilik \& kolektivizm, bireylerin ben merkezlimi yoksa biz merkezli hareket ettiğini yansıtır. Hofstede ve McCree (2004) yapmış olduğu çalışmada gelişmiş batılı toplumlarının bireyci, az gelişmiş doğu toplumlarının ise kolektivist yapıya sahip olduğunu belirtmektedir. Bireyselliğin ön plana çıktığı toplumların karmaşıklık düzeyleri yüksek olmakta ve özgürlük son derece önemli görülmektedir. Bununla birlikte, kolektivist toplumlarda ise basit ve kuşatıcı bir yapı görülmektedir (Triandis, 2000: 147). Bireycilik, kişilerin benmerkezci bir benlik kavramını yansıtmakta, kolektivizm ise kişinin biz merkezci bir benlik kavramını yansıtmaktadır. Bireyselliği benimsemiş kişilerde, bireysel hedefleri ön plana çıkarma, diğer bireylere karşı mesafeli olma, kendine güvenme ve rekabetçi olma gibi özellikleri ön plana çıkmaktadır. Kolektivist bir benliği benimsemiş bireylerde, grup hedeflerine öncelik verme, sosyalleşme, karşılıklı yardımlaşma ve bağımlıık ön plana çıkmaktadır (Triandis, 2001: 909, Triandis ve Suh, 2002: 139).

Bireyciler, benliğin hayatta kalmanın temeli olduğuna inanırlar. Öte yandan, kolektivistler ise hayatta kalmanın bir veya birkaç gruba dâhil olmaya bağlı olduğuna inanırlar. Triandis (1995) bireycilik-kolektivizmin çok boyutlu olduğunu savunmaktadır. Hem bireyciliğin hem de kolektivizmin eşitliği vurgulayan (yatay) ve hiyerarşiyi vurgulayan (dikey) uzantılarının olabileceğini öne sürmüştür. Eşitliği vurgulayan yatay yapı, kişilerin benliklerinin birbirlerine benzer olduğunu ifade etmektedir. Hiyerarşiyi vurgulayan dikey yapı ise kişilerin benlik yapılarının 
diğerlerinden farklı olduğunu ifade etmektedir. Bu bağlamda, bireycilik ve kolektivizmin, yatay ve dikey yapı birleşimi dört farklı kültürel modeli ortaya çıkartmaktadır; yatay kolektivizm, dikey kolektivizm, yatay bireycilik ve dikey bireycilik.

Yatay kolektivizmde bireyler, bulunduğu grubun refahını önemseyen, fakat bağımlılık hissetmeyen, empati, sosyallik ve işbirliğinin ön plana çıktığı bir yapıya sahiptir. Dikey kolektivizmde bireyler, otoriteye ve kendi gruplarının normlarına boyun eğen, gelenekçi ve grubu için kendi kimliğini feda edebilen bir yapıya sahiptir. Yatay bireyci kişiler, diğerlerinden bağımsız ve benzersiz olduğunu düşünür, hiyerarşik farklılaşmanın olmadığına inanır ve kendine güvenen bir yapıya sahiptir. Dikey bireyci kişiler, kendilerini başkalarıyla karşılaştırır, yüksek rekabet güdüsüne sahiptir ve en iyi olma çabası içerisinde olan bir yapıya sahiptir (Chiou, 2001: 668; Triandis ve Suh, 2002: 139-140).

Öz-güven, "bireyin sahip olduğu yetenek, güç ve kararlarına güvenmesi ve belli bir eylemi başarılı bir şekilde yerine getirebileceğine olan inancı" olarak tanımlanmaktadır (Feltz, 1988: 423). Kişiliği oluşturan bir kavram olan öz-güven, bireyin kendisini değerli hissetmesine yönelik oluşan bir yargısıdır. Öz-güvende, kişinin ruh sağlığı, yakaladığı başarılar ya da yaşadığı mutluluklar ön plana çıkmaktadır. Ayrıca, öz-güven, bireylerin istediği gibi davranabilmesi için önemli bir itici güç olarak görülmektedir (Kaya ve Taştan, 2020: 298).

\subsection{Liderlik Etme Motivasyonu}

Liderlik, "başkalarının ne yapılması gerektiğini ve nasıl yapılacağını anlamaları için etkileme süreci ve ortak hedeflere ulaşmak için bireysel ve toplu çabaları kolaylaştırma süreci” olarak tanımlamaktadır (Yukl, 2013: 7). Bu liderlik sürecinde, kişilerin diğerlerine liderlik yapmaya iten bir motivasyonun olması gerekmektedir. Chan ve Drasgow (2001) çalışmalarında kişilerin liderlik rolünü üstlenmesinin altında yatan motivasyonu araştırmıştır. Liderlik etme motivasyonu, "liderin, liderlik rolleri ve sorumluluklarını üstlenme kararını etkileyen ve liderlik noktasındaki çabaları ve ısrarını etkileyen bireysel farklılıklar yapısı” olarak tanımlanmaktadır (Chan ve Drasgow, 2001: 482).

Bireylerin liderlik rolünü üstlenme noktasında üç temel belirleyicisi bulunmaktadır (Chan ve Drasgow, 2001; Chan vd., 2000; Hong vd., 2011; Özbezek ve Paksoy, 2017):

Duygusal Kimlik: Bir bireyin başkalarına liderlik etme noktasındaki doğal eğilimini, öz-yeterliliğini ve bireyin liderlik rolüne verdiği değeri yansıtmaktadır. Özünde lider olmakla ilgilenenler bireyler, hiçbir baskı olmaksızın liderlik rolünü üstlenmek için inisiyatif alarak lider olmak için adım atabilirler. Bireylerin liderlik rolünü üstlenmesindeki içsel motivasyonunu yansıtmaktadır.

Sosyal-Normatif: Bireyin bir görev veya sorumluluk duygusu ile diğerlerine liderlik etme eğilimini yansıtmaktadır. Bireylerin liderlik rollerini üstlenmeye ilişkin normatif inançlarını kapsar. Ayrıca, bireyin görev ve sorumluluk duygusu ile liderlik etmesini sağlayan dışsal bir motivasyon kaynağını oluşturmaktadır.

Çıkarsız Yaklaşım: Bir bireyin liderlik rolünü üstlenmedeki maliyet ve faydalarını hesaplamadan, yönetmeyi kabul edip etmeyeceği noktasındaki tutumunu yansıtmaktadır. Ayrıca, bu durum bireyin fedakârlık ve özveri düzeyiyle ilişkili motivasyonunu yansıtmaktadır. Liderlik rolünü üstlenmenin avantaj veya dezavantajlarını hesaplamayan bireylerin liderliği üstlenme noktasında daha istekli olabilirler.

\section{ARAŞTIRMA METODOLOJISi}

\subsection{Araştırmanın Amacı, Kapsamı ve Yöntemi}

Bu çalışmada, potansiyel işgücü olarak görülen Z kuşağının bireycilik \& kollektivizm kültürel eğilimlerinin ve öz güven seviyelerinin liderlik etme motivasyonuna olan etkisini belirlemek amaçlanmaktadır. Bu doğrultuda, gerekli olan veriler Kütahya Dumlupınar Üniversitesi öğrencilerinden elde edilmiştir. Araştırma kapsamında, üniversite öğrencileri ana kitle olarak seçilmiş ve özellikle 2000 yılı öncesi doğan Z kuşağı hedef kitle olarak seçilmiştir. 2020 Mayıs-2021 Ocak döneminde, kolayda örneklem yöntemine göre 500 öğrenciye anket formu online olarak ulaştırılmıştır. Analiz yapmaya uygun 297 anket formu dönüşü sağlanmıştır. Anket formunda; yaş, cinsiyet, bireycilik \& kolektivizm, özgüven ve liderlik etme motivasyonunu ölçmeye yönelik 48 soru yer almaktadır.

\subsection{Verilerin Toplanması ve Analizi}

Araştırma için gerekli olan veriler anket aracılığı elde edilmiştir. Araştırmada, bireycilik \& kollektivizm, öz güven ve liderlik etme motivasyonundan oluşan üç ölçek kullanılmaktadır. Singelis vd. (19985) tarafından geliştirilen dört alt boyuttan (yatay bireycilik, dikey bireycilik, yatay kollektivizm, dikey kollektivizm) ve 16 ifadeden oluşan bireycilik \& kolektivizm ölçeği kullanılmıştır. Lumpkin ve Hunt (1989) tarafından geliştirilen ve üç ifadeden oluşan öz-güven ölçeği kullanılmıştır. Chan ve Drasgow (2001) tarafından geliştirilen, üç alt boyuttan (duygusal kimlik, çıkarsız yaklaşım, sosyal normatif) ve 27 ifadeden oluşan liderlik etme motivasyonu ölçeği kullanılmıştır. Ölçeklerde kullanılan ifadeler 5'li likert tipi derecelendirme (1=Kesinlikle Katılmıyorum - 5=Kesinlikle Katılıyorum) aralığı kullanılmıştır. Anket yoluyla elde edilen veriler açıklayıcı ve doğrulayıcı faktör analizine tabi tutulmuş, değişkenler arasındaki ilişkiyi ortaya koymak için ise korelasyon analizi yapılmıştır. Hipotezlerin test edilmesi için çoklu regresyon analizi yapılmıştır.

\subsection{Araştırma Modeli ve Hipotezler}

Araştırmanın amacı doğrultusunda, bireycilik \& kolektivizm ve öz-güvenin liderlik etme motivasyonuna etkisini konu alan hipotezler geliştirilmiştir:

$\mathrm{H}_{1}$ : Yatay bireyselliğin liderlik etme motivasyonun alt faktörleri üzerinde pozitif yönlü anlamlı bir etkisi vardır.

$\mathrm{H}_{2}$ : Dikey bireyselliğin liderlik etme motivasyonun alt faktörleri üzerinde pozitif yönlü anlamlı bir etkisi vardır. 
$\mathrm{H}_{3}$ : Yatay kolektivizmin liderlik etme motivasyonun alt faktörleri üzerinde pozitif yönlü anlamlı bir etkisi vardır.

$\mathrm{H}_{4}$ : Dikey kolektivizmin liderlik etme motivasyonun alt faktörleri üzerinde pozitif yönlü anlamlı bir etkisi vardır.

$\mathrm{H}_{5}$ : Öz-güvenin liderlik etme motivasyonun alt faktörleri üzerinde pozitif yönlü anlamlı bir etkisi vardır.

Şekil 1: Araştırma Modeli

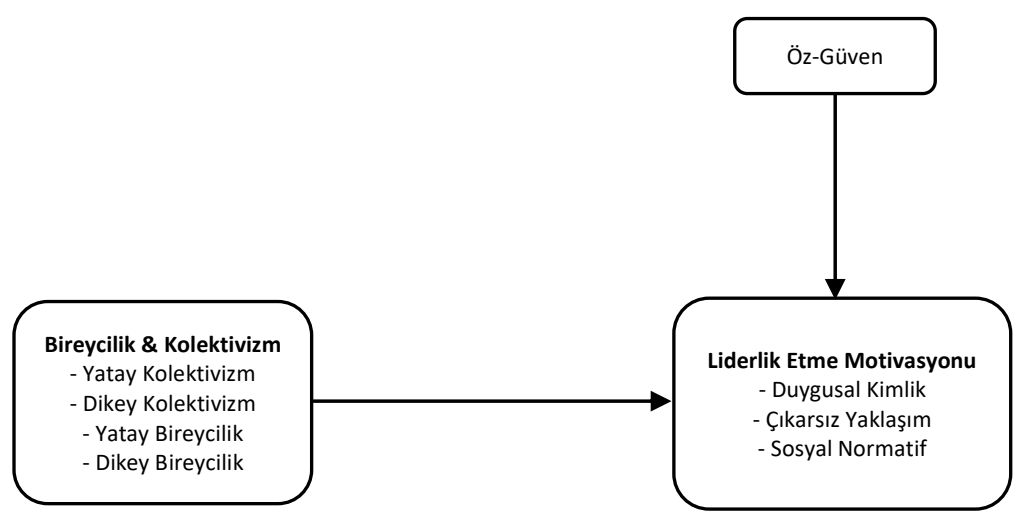

\section{ARAŞTIRMA BULGULARI}

Araştırmada kullanılan ölçeklerin faktör yapılarını tespit etmek, güvenilirlik ve geçerliliğini belirlemek için açıklayıcı ve doğrulayıcı faktör analizi yapılmıştır. Ölçekler Varimax rotasyon yöntemi kullanılarak ayrı ayrı temel birleşenler faktör analizine tabi tutulmuştur. Açıklayıcı faktör analizi sonucuna göre; duygusal kimlik boyutuna ait üç ifade, çıkarsız yaklaşım boyutundan iki ifade, sosyal-normatif boyutundan üç ifade ve yatay kolektivizm boyutundan bir ifade aynı anda farklı boyutlara yüklendiğinden ve faktör yükleri 0,5'in altında olduğundan dolayı analizden çıkarılmıştır. Yenilenen açıklayıcı faktör analiz sonucunda ölçeklere ait KMO değerlerinin 0,651-0,822 arasında olduğu; Cronbach Alfa değerinin 0,607-0,718 arasında olduğu; açıklanan toplam varyans değerleri 0,53-0,63 arasında olduğu belirlenmiştir. Her bir faktör ve ölçek için sonuçların açıklayıcı faktör analizi yapılması için yeterli olduğu sonucuna ulaşılmıştır. Açıklayıcı faktör analizi sonucunda ise faktörleri oluşturan ifadelerin faktör yüklerinin 0,509-0,858 arasında olduğu tespit edilmiştir. Tüm bu sonuçlar kullanılan ölçeklerin faktör yapılarının düzgün dağıldığı ve güvenilir olduğunu göstermektedir (Kalaycı, 2016: 405).

Öz güven, bireycilik \& kolektivizm, ve liderlik etme motivasyonu ölçeklerinin doğrulayıcı faktör analiz sonuçlarına göre elde edilen uyum indeks değerleri; Bireycilik \& Kolektivizm (X²/sd: 1,883; NFI: 0,83; CFI: 0,910; RMSEA: 0,055; GFI: 0,938; RMR: 0,08), Liderlik Etme Motivasyonu (X²/sd: 1,935; NFI: 0,901; CFI: 0,948; RMSEA: 0,056; GFI: 0,910; RMR: 0,099), Öz-Güven ölçeği ifadeden oluştuğundan dolayı DFA analizi uygulanmamıştır. Doğrulayıcı faktör analizi sonucunda, ölçeklere ilişkin uyum iyiliği değerleri genel itibariyle kabul edilebilir uyum değer aralığında olduğu görülmektedir. Ayrıca, açıklayıcı ve doğrulayıcı faktör analizi sonuçlarında ifadelere ilişkin $p$ anlamlılık $p<0,01$ olduğu ve ifadelere ilişkin t değerlerinin 2,56’yı aştığı gözlemlenmektedir. Bu sonuçlar ölçeklerin istatistiksel olarak anlamlı olduğunu ortaya koymaktadır (Çokluk vd. 2016: 303-304).

Korelasyon analiziyle birlikte ölçeklere ilişkin ortalamalar, standart sapmalar ve korelasyon değerleri hesaplanmıştır. Bu değerler Tablo 1'de ayrıntılı olarak verilmektedir.

Tablo 1: Ortalama, Standart Sapma ve Korelasyon Değerleri

\begin{tabular}{|c|l|c|c|c|c|c|c|c|c|c|}
\hline & Değişkenler & Ort. & S.S. & $\mathbf{1}$ & $\mathbf{2}$ & $\mathbf{3}$ & $\mathbf{4}$ & $\mathbf{5}$ & $\mathbf{6}$ & $\mathbf{7}$ \\
\hline $\mathbf{1}$ & Yatay Kolektivizm & 4,2604 &, 62804 & 1 & & & & & & \\
\hline $\mathbf{2}$ & Dikey Kolektivizm & 3,8030 &, 85048 & $0,327^{* *}$ & 1 & & & & \\
\hline $\mathbf{3}$ & Yatay Bireycilik & 3,7778 &, 78485 & $0,145^{*}$ & 0,051 & 1 & & & & \\
\hline $\mathbf{4}$ & Dikey Bireycilik & 3,2096 &, 87816 & $0,15^{* *}$ & 0,101 & $0,263^{* *}$ & 1 & & & \\
\hline $\mathbf{5}$ & Duygusal Kimlik & 2,5140 & 1,0121 & $-0,139^{*}$ & $0,15^{* *}$ & $-0,076$ & $-0,212^{* *}$ & 1 & & \\
\hline $\mathbf{6}$ & Çıkarsız Yaklaşım & 4,1607 &, 57049 & $0,133^{*}$ & 0,085 & $-0,077$ & $-0,147^{*}$ & $-0,032$ & 1 & \\
\hline $\mathbf{7}$ & Sosyal Normatif & 3,3042 &, 87909 & $0,299^{* *}$ & $0,316^{* *}$ & 0,085 & $0,226^{* *}$ & $-0,305^{* *}$ & $-0,044$ & 1 \\
\hline $\mathbf{8}$ & Öz-Güven & 3,2233 & 1,0137 & $0,316^{* *}$ & 0,071 & $0,398^{* *}$ & $0,286^{* *}$ & $-0,41^{* *}$ & $-0,078$ & $0,295^{* *}$ \\
\hline
\end{tabular}

$* p<0,05 ; * * p<0,01$ 
Korelasyon analizi sonucuna göre ile dikey kolektivizm, yatay kolektivizm, dikey bireycilik ve öz güven ile liderlik etme motivasyonun alt boyutları arasında pozitif yönlü anlamlı ilişkilerin olduğu görülmektedir.

\section{HIPOTEZLERIN TEST EDILMESi}

Korelasyon analizi ile değişkenler arasında tespit edilen ilişki sonrasında, bağımsız değişkenlerin bağımlı değişkenlere olan etkisinin şiddeti ve yönü ölçülmek için çoklu regresyon analizi yapılmıştır. Regresyon analizi sonuçları Tablo 2'de ayrıntılı olarak verilmektedir.

Tablo 2: Regresyon Analizi Sonuçları

\begin{tabular}{|c|c|c|c|c|c|c|}
\hline \multirow[b]{3}{*}{ Bağımsız Değişken } & \multicolumn{6}{|c|}{ Bağımlı Değişkenler } \\
\hline & \multicolumn{2}{|c|}{ Duygusal Kimlik } & \multicolumn{2}{|c|}{ Çıkarsız Yaklaşım } & \multicolumn{2}{|c|}{ Sosyal-Normatif } \\
\hline & $\beta$ & $\mathbf{t}$ & $\beta$ & $\mathbf{t}$ & $\beta$ & $\mathbf{t}$ \\
\hline Öz-Güven & $-0,412^{* *}$ & $-6,914$ & $-0,08$ & $-1,220$ & $0,224 * *$ & 3,706 \\
\hline Yatay Kolektivizm & $-0,076$ & $-1,319$ & $0,168^{* *}$ & 2,648 & 0,139* & 2,389 \\
\hline Dikey Kolektivizm & $0,212 * *$ & 3,877 & 0,052 & 0,867 & $0,245^{* *}$ & 4,422 \\
\hline Yatay Bireycilik & $0,125^{*}$ & 2,191 & $-0,033$ & $-0,526$ & $-0,072$ & $-1,249$ \\
\hline Dikey Bireycilik & $-0,137^{*}$ & $-2,500$ & $-0,146 *$ & $-2,408$ & $0,136^{*}$ & 2,450 \\
\hline $\mathbf{R}^{2}$ & \multicolumn{2}{|c|}{0,231} & \multicolumn{2}{|c|}{0,057} & \multicolumn{2}{|c|}{0,209} \\
\hline $\mathbf{R}$ & \multicolumn{2}{|c|}{0,480} & \multicolumn{2}{|c|}{0,239} & \multicolumn{2}{|c|}{0,458} \\
\hline $\mathbf{F}$ & \multicolumn{2}{|c|}{17,445} & \multicolumn{2}{|c|}{3,521} & \multicolumn{2}{|c|}{15,414} \\
\hline
\end{tabular}

$* p<0,05 ; * * p<0,01$

Regresyon analizi sonucuna göre; yatay bireyselliğin $(\beta=0,125 ; t=2,191 ; p<0,05)$ duygusal kimlik liderlik etme motivasyonu üzerinde anlamlı olumlu bir etkiye sahiptir. Dikey bireyselliğin $(\beta=0,136 ; t=2,40 ; p<0,05)$ sosyal-normatif liderlik etme motivasyonu üzerinde anlamlı olumlu bir etkiye sahiptir. Yatay kolektivizm $(\beta=0,168 ; t=2,648 ; p<0,01)$ çıkarsız liderlik etme motivasyonu ve $(\beta=0,139 ; t=2,389 ; p<0,05)$ sosyalnormatif liderlik etme motivasyonu üzerinde anlamlı olumlu bir etkiye sahiptir. Dikey kolektivizm $(\beta=0,212 ; t=3,877 ; p<0,01)$ duygusal kimlik liderlik etme motivasyonu ve $(\beta=0,245 ; t=4,422 ; p<0,01)$ sosyal-normatif liderlik etme motivasyonu üzerinde anlamlı olumlu bir etkiye sahiptir. Öz-güven $(\beta=0,224 ; t=3,706 ; p<0,01)$ sosyal-normatif liderlik etme motivasyonu üzerinde anlamlı olumlu bir etkiye sahiptir. Elde edilen sonuçlara göre; $\mathrm{H}_{1}, \mathrm{H}_{2}, \mathrm{H}_{3}, \mathrm{H}_{4}$ ve $\mathrm{H}_{5}$ hipotezleri kabul edilmiştir.

\section{SONUÇ}

Teknolojik, ekonomik, sosyal, politik vb. değişimlerin hızlı yaşandığı günümüz dünyasında, bu değişime bağıı olarak, bireylerin amaçlarında, değerlerinde, yargılarında, tutumlarında, davranışları ve birçok özelliklerinde belirgin değişimler meydana gelmiştir. Her nesil bir önceki nesile göre bariz farklııklar taşımakta olup, ihtiyaçları ve beklentileri değişmektedir. Bu bağlamda, dijital teknoloji çağında doğan ve iş hayatına yeni yeni girmeye başlayan z kuşağı bireylerinin birçok farklı açıdan incelenmesi önem taşımaktadır. Bu çalışmada, potansiyel işgücü olarak görülen Z kuşağının bireycilik \& kolektivizm kültürel eğilimlerinin ve öz-güven seviyelerinin, liderlik etme motivasyonuna olan etkisini belirlemek amaçlanmaktadır.

Araştırma sonuçlara göre; bireylerin öz-güveninin sosyal-normatif liderlik etme motivasyonu üzerinde anlamlı ve pozitif etkisi bulunmaktadır. Buna karşın, öz-güveninin çıkarsız liderlik etme motivasyonuna etkisi bulunmazken, duygusal kimlik, liderlik etme motivasyonu üzerinde negatif yönlü anlamlı bir etkisi bulunmaktadır. Bu sonuca göre, z kuşağı bireylerin öz-güvenin yüksek olması durumunda liderlik etme noktasında dışsal olarak motive olduğu söylenebilir. Yatay kolektivizmin, sosyal-normatif ve çıkarsız liderlik etme motivasyonu üzerinde anlamlı ve pozitif etkisi bulunmaktadır. Buna karşın, yatay kolektivizmin duygusal kimlik liderlik etme motivasyonu üzerinde etkisi bulunmamaktadır. Bu sonuca göre, karş̧ıkı bağımlılık ve diğerleri ile ortak hedeflere sahip z kuşağı bireylerin, liderlik etme noktasında fedakârlık göstermesi ve dışsal olarak motive olabildiği söylenebilir. Dikey kolektivizm, sosyal-normatif ve duygusal kimlik liderlik etme motivasyonu üzerinde anlamlı ve pozitif etkisi bulunmaktadır. Buna karşın, dikey kolektivizmin çıkarsız liderlik etme motivasyonu üzerinde etkisi bulunmamaktadır. Bu sonuca göre, otoritenin normlarına boyun eğen, grubu için kendi kimliğini feda edebilen z kuşağı bireylerin, liderlik etme noktasında hem içsel hem de dışsal motive olabildiği söylenebilir. Yatay bireyciliğin, duygusal kimlik liderlik etme motivasyonu üzerinde anlamlı ve pozitif etkisi bulunmaktadır. Buna karşın, yatay bireyciliğin sosyal-normatif ve çıkarsız liderlik etme motivasyonu üzerinde etkisi bulunmamaktadır. Bu sonuca göre, kendi içinden geldiği gibi davranan, kendine güvenen ve benzersiz olmaya çalışan z kuşağı bireylerin, liderlik etme noktasında sadece içsel olarak motive olduğu söylenebilir. Dikey bireyciliğin, sosyal-normatif liderlik etme motivasyonu üzerinde anlamlı ve pozitif etkisi bulunmaktadır. Buna karşın, dikey bireyciliğin duygusal kimlik ve çıkarsız liderlik etme motivasyonu üzerinde negatif yönlü anlamlı bir etkisi bulunmaktadır. Bu sonuca göre, rekabetçi, ayrıcalıklı olmak isteyen ve statü elde etmeye çalışan z kuşağı bireylerin liderlik etme noktasında sadece dışsal olarak motive olduğu söylenebilir.

Elde edilen tüm bu sonuçlar Chan ve Drasgow (2001) yapmış olduğu araştırma sonuçlarılla farklılık göstermektedir. Chan ve Drasgow (2001) araştırmasında, dikey bireyselliğin sosyal-normatif ve duygusal kimlik liderlik etme motivasyonu üzerinde anlamlı ve pozitif etkisi olduğunu bulmuştur. Yatay bireyciliğin, sosyal-normatif ve çıkarsız liderlik etme motivasyonu üzerinde negatif yönlü anlamlı bir etkisi olduğunu 
bulmuştur. Ayrıca, kolektivizmin, sosyal-normatif ve çıkarsız liderlik etme motivasyonu üzerinde olumlu yönlü anlamlı bir etkisi olduğunu bulmuştur. Bu farklııkların, z kuşağının diğer kuşaklara göre tutumsal ve davranışsal farklıı̆ından kaynaklanma intimali yüksektir. Yakın geleceğin işgücünü temsil eden z kuşağı bireylerin, motivasyon kaynaklarına yönelik detaylı araştırmaların yapılması hem akademik açıdan hem de iş hayatı açısından büyük önem arz etmektedir.

\section{KAYNAKÇA}

Altuntuğ, N. (2012). Kuşaktan kuşağa tüketim olgusu ve geleceğin tüketici profili. Organizasyon ve Yönetim Bilimleri Dergisi, 4(1): $203-212$.

Chan, K. Y. \& Drasgow, F. (2001). Toward a theory of individual differences and leadership: Understanding the motivation-to-lead. Journal of Applied Psychology, 86(3): 481-498.

Chan, K. Y., Rounds, J. \& Drasgow, F. (2000). The relation between vocational interests and the motivation to lead. Journal of Vocational Behavior, 57(2): 226-245.

Chiou, J. S. (2001). Horizontal and vertical individualism and collectivism among college students in the United States, Taiwan, and Argentina. The Journal of Social Psychology, 141(5): 667-678.

Çokluk, Ö., Şekercioğlu, G. \& Büyüköztürk, Ş. (2016). Sosyal bilimler için çok değişkenli istatistik SPSS ve LISREL uygulamaları (4. Baskı), Ankara: Pegem Akademi Yayınları.

Düzgün, A. (2020). Y ve Z kuşaklarının iş hayatından beklentilerinin karşılaştırılması. Hitit Üniversitesi Sosyal Bilimler Enstitüsü Dergisi, 13(1): 218-241.

Feltz, D. L. (1988). Self-confidence and sports performance. Exercise and Sport Sciences Reviews, 16(1): 423-458.

Hofstede, G. \& McCrae, R. R. (2004). Personality and culture revisited: linking traits and dimensions of culture. Cross-Cultural Research, 38(1): $52-88$.

Hong, Y., Catano, V. M. \& Liao, H. (2011). Leader emergence: the role of emotional intelligence and motivation to lead. Leadership \& Organization Development Journal, 32(4): 320-343.

Kalaycı, Ş. (2016). SPSS uygulamalı çok değişkenli istatistik teknikleri, Ankara: Asil Yayınları.

Kaya, N. \& Taştan, N. (2020). Özgüven üzerine bir derleme, Kırıkkale Üniversitesi Sosyal Bilimler Dergisi, 10(2): $297-312$.

Levickaite, R. (2010). Generations X, Y, Z: How social networks form the concept of the World without borders (the case of Lithuania). LIMES: Cultural Regionalistics, 3(2): 170-183.

Lumpkin, J. R. \& Hunt, J. B. (1989). Mobility as an influence on retail patronage behavior of the elderly: Testing conventional wisdom. Journal of the Academy of Marketing Science, 17(1): 1-12.

Özbezek, B. D. \& Paksoy, H. M. (2017). Liderlik etme motivasyonu ve duygusal zekâ arasındaki ilişkide öz yeterliliğin rolü üzerine bir araştırma. International Journal of Disciplines Economics \& Administrative Sciences Studies, 3(4): 248-269.

Singelis, T. M., Triandis, H. C., Bhawuk, D. \& Gelfand, M. L. (1995). Horizontal and verticaldimensions of individualism and collectivism: A theoretical and measurement refinement. Cross-Cultural Research, 29(3): 240-75.

Sladek, B. S. \& Grabinger, A. (2016). The first generation of the 21st Century has arrived!, Erişim: 22.02.2021, https://www.xyzuniversity.com/wp-content/uploads/2018/08/GenZ_Final-dl1.pdf.

Taş, H. Y., Demirdöğmez, M. ve Küçükoğlu, M. (2017). Geleceğimiz olan Z kuşağının çalışma hayatına muhtemel etkileri. OPUS - Uluslararası Toplum Araştırmaları Dergisi, 7(13): 1031-1048.

Triandis, H. C. (1995). Individualism and collectivism. Boulder, CO: Westview Press.

Triandis, H. C. (2000). Culture and conflict. International Journal of Psychology, 35(2): 145-152.

Triandis, H. C. (2001). Individualism-collectivism and personality. Journal of Personality, 69(6): 907-924.

Triandis, H. C. ve Suh, E M. (2002). Cultural influences on personality, Annual Review of Psychology, Academic Research Library, 53, $133-160$. Yukl, G. A. (2013). Leadership in organizations. Boston: Pearson. 